\title{
Effect of Stepwise Replacement of Non-Oxide to Oxide Group on Structural Properties of $\mathrm{Bi}_{2} \mathrm{O}_{3} \cdot \mathrm{LiF} \cdot \mathrm{B}_{2} \mathrm{O}_{3}$ Glasses
}

\author{
Susheel Arora, ${ }^{1}$ Virender Kundu, ${ }^{2}$ D. R. Goyal, ${ }^{1}$ and A. S. Maan ${ }^{1}$ \\ ${ }^{1}$ Department of Physics, Maharshi Dayanand University, Rohtak 124 001, India \\ ${ }^{2}$ Department of Electronic Science, Kurukshetra University, Kurukshetra 136 119, India
}

Correspondence should be addressed to Susheel Arora, susheel_arora@yahoo.com

Received 2 August 2012; Accepted 28 August 2012

Academic Editors: V. Di Noto, A. A. Ensafi, and S. Yannopoulos

Copyright (c) 2012 Susheel Arora et al. This is an open access article distributed under the Creative Commons Attribution License, which permits unrestricted use, distribution, and reproduction in any medium, provided the original work is properly cited.

\begin{abstract}
Bismuth fluoroborate glasses with compositions $x \mathrm{Bi}_{2} \mathrm{O}_{3} \cdot(40-x) \mathrm{LiF} \cdot 60 \mathrm{~B}_{2} \mathrm{O}_{3}(x=0,5,10,15$, and 20) are synthesized by meltquench method. XRD pattern is obtained for all the samples to confirm their amorphous nature. FTIR spectroscopy is carried out for the reported samples. It reflects the effect of replacement of a non-oxide group ( $\mathrm{LiF})$ with an oxide group $\left(\mathrm{Bi}_{2} \mathrm{O}_{3}\right)$ in the glass network, due to the presence of the various absorption bands and their shifting with such replacement, assigning a role of network modifier to $\mathrm{Bi}_{2} \mathrm{O}_{3}$. Density and molar volume show an increase in their values with increase in $\mathrm{Bi}_{2} \mathrm{O}_{3}$ concentration. Theoretical optical basicity is calculated for the reported samples, which shows a decreasing trend with the increasing concentration of $\mathrm{Bi}_{2} \mathrm{O}_{3}$.
\end{abstract}

\section{Introduction}

$\mathrm{B}_{2} \mathrm{O}_{3}$ is one of the best glass formers due to the sheet-like structure of boron-oxygen triangles in borate glasses, with their ability to connect themselves to form a network $[1,2]$. A random arrangement of various atomic and molecular species is easily formed in borate glasses which is the basic requirement for glass formation. A number of modifications in the properties of the borate glasses, with the addition of alkali halides, have been reported so far [3-9]. The inclusion of LiF in the borate glass network brings out some structural changes [3], which in turn become responsible for the change in various properties. Some new units like $\mathrm{BO}_{2} \mathrm{~F}, \mathrm{BO}_{2} \mathrm{~F}_{2}$, $\mathrm{BOF}_{3}$, and $\mathrm{BO}_{3} \mathrm{~F}$ are formed by the replacement of few oxygen atoms by fluorine ions [4-6]. Also, there may be an increase in the number of polyhedral groups of boron and oxygen, which in turn increases the number of nonbridging oxygen atoms [7-9].

$\mathrm{Bi}_{2} \mathrm{O}_{3}$ possesses high third-order nonlinear optical susceptibility caused by high density and refractive index $[10,11]$. This property makes it to have numerous nonlinearity applications such as optical switching [12, 13], supercontinuum generation [14], and wavelength conversion [15]. Luminescent materials have always been studied by researchers for their wide range of applications. Noto reported the luminescence spectroscopy of some systems containing rare earth ions $[16,17]$. Also, bismuth ion acts as an efficient luminescent activator with applications in lasers as a sensitizer for some rare earth ions $[18,19]$. The purpose of this paper is to report the change in structural and physical properties of $\mathrm{LiF}-\mathrm{B}_{2} \mathrm{O}_{3}$ glasses with the stepwise replacement of $\mathrm{LiF}$ by $\mathrm{Bi}_{2} \mathrm{O}_{3}$. The addition of $\mathrm{Bi}_{2} \mathrm{O}_{3}$ provides an opportunity for the new molecular units to be formed with more numbers of NBOs.

\section{Experimental Details}

$\mathrm{Bi}_{2} \mathrm{O}_{3}$ containing fluoroborate glasses with compositions $x \mathrm{Bi}_{2} \mathrm{O}_{3} \cdot(40-x) \mathrm{LiF} \cdot 60 \mathrm{~B}_{2} \mathrm{O}_{3}(x=0,5,10,15$, and 20$)$ were synthesized through melt-quench method using $\mathrm{Bi}_{2} \mathrm{O}_{3}$, $\mathrm{LiF}$ and $\mathrm{H}_{3} \mathrm{BO}_{3}$, reagent grade powders. A uniform mixture of the various powdered samples was prepared and heated at $1273 \mathrm{~K}$ for 30 minutes. The bubble free melt so formed was pressed between two carbon plates at room temperature. The glassy samples were thus obtained in the form of thin pallets.

The samples were tested for their amorphous nature on Rigaku X-ray diffractometer using $\mathrm{Cu}-\mathrm{K} \alpha$ radiations. The samples grinded to powdered form were placed in the diffractometer and rotated at $1 \% \mathrm{~min}$. 
FTIR spectroscopy was carried out at room temperature in the range from 652 to $4000 \mathrm{~cm}^{-1}$. The samples were exposed to the IR radiations in Perkin-Elmer FTIR spectrophotometer. A plot between \% transmission and wave number is obtained to examine various bonds formation in view of absorption bands obtained in the plot.

Densities $(d)$ of the samples were calculated at room temperature using Archimedes' principle with xylene was taken as an inert immersion liquid.

\section{Results and Discussion}

3.1. XRD Analysis. The $\mathrm{X}$-ray diffraction pattern for $x \mathrm{Bi}_{2} \mathrm{O}_{3}$. $(40-x) \mathrm{LiF} \cdot 60 \mathrm{~B}_{2} \mathrm{O}_{3}$ glasses with $x=0,5,10,15$ and 20 is plotted in Figure 1. The patterns contain broad bands but do not contain any peak, which confirms the amorphous nature of the samples.

3.2. FTIR Analysis. Figure 2 corresponds to the Fourier transform infrared spectra of the compositions $x \mathrm{Bi}_{2} \mathrm{O}_{3}-$ $(40-x)-60 \mathrm{~B}_{2} \mathrm{O}_{3}$, with $x=0,5,10,15$, and 20 . The spectra were recorded in the range, $652-4000 \mathrm{~cm}^{-1}$. However, absorption bands obtained in the range of $1700-4000 \mathrm{~cm}^{-1}$ correspond to those due to water groups, the said range is not shown in the figure.

In the composition with $x=0$, there appears an absorption band around $685 \mathrm{~cm}^{-1}$. This absorption is attributed to the bending of B-O-B linkage in the borate network [20]. However for the compositions with $x=5,10,15$, and 20, in general, this absorption becomes very weak which reveals that the structural changes are taking place due to the addition of $\mathrm{Bi}_{2} \mathrm{O}_{3}$. For all the samples, there appears an absorption band with small but increasing intensity, around $779 \mathrm{~cm}^{-1}$. This absorption is due to the formation of $\mathrm{B}-\mathrm{F}$ bonds [21]. This indicates that due to addition of $\mathrm{Bi}_{2} \mathrm{O}_{3}$, structure of the glass is greatly affected as fluorine gets encouraged to take interstitial positions in the glass network. In the composition with $x=0$, the absorption band around $910 \mathrm{~cm}^{-1}$ is attributed to the $\mathrm{B}-\mathrm{O}$ bond stretching in $\mathrm{BO}_{4}$ units of diborate groups [22]. In the compositions except $x=0$, there appears another band originating at $901 \mathrm{~cm}^{-1}$. Intensity of this band increases with increase in $\mathrm{Bi}_{2} \mathrm{O}_{3}$ concentration. It may be due to the $\mathrm{Bi}-\mathrm{O}$ and $\mathrm{Bi}-\mathrm{O}-\mathrm{Bi}$ bonds in $\mathrm{BiO}_{6}$ octahedra [20, 21, 23-25].

For the samples with $x=5,10,15$ and 20, inclusion of $\mathrm{Bi}_{2} \mathrm{O}_{3}$ in the host composition facilitates the presence of more oxygen atoms in the glass network. The availability of these oxygen atoms encourages the formation of more pentaborate and diborate species $[26,27]$ in the glass network. Presence of these species is attested by the increasing intensity band in $x=5,10,15$, and 20 at $1100 \mathrm{~cm}^{-1}$, which is almost absent in $x=0$.

In the literature $[22,26,28]$, the absorption range 1160 $1600 \mathrm{~cm}^{-1}$ is assigned to the $\mathrm{B}-\mathrm{O}$ bond stretching vibrations in $\mathrm{BO}_{3}$ units. Here one can observe two sub-bands in all the compositions. For $x=0$, the sub-bands are centered at $1220 \mathrm{~cm}^{-1}$ and $1365 \mathrm{~cm}^{-1}$. The former band corresponds to the stretching vibrations of $\mathrm{B}-\mathrm{O}$ bonds in $\mathrm{BO}_{3}$ units from meta and ortho-borate groups [21, 22, 25-28] and the later is due to the $\mathrm{B}-\mathrm{O}$ asymmetric stretching vibrations in $\mathrm{BO}_{3}$ and $\mathrm{BO}_{3}{ }^{-}$units $[22,25,26]$. For the compositions other than $x=0$, these sub-bands appear at $1210 \mathrm{~cm}^{-1}$ and $1370 \mathrm{~cm}^{-1}$ respectively, with an enhanced intensity. The enhancement in the intensity of the band centered at $1210 \mathrm{~cm}^{-1}$ may be due to the formation of more $\mathrm{BO}_{3}$ units in meta and ortho borate groups with the addition of oxygen containing $\mathrm{Bi}_{2} \mathrm{O}_{3}$ molecule in the glass network. The increasing intensity of the band centered at $1370 \mathrm{~cm}^{-1}$ is due to the presence of $\mathrm{BiO}^{-}$units in the samples other than that with $x=0$ [23]. In addition to these two high-intensity bands, there exists a shoulder absorption at $1295 \mathrm{~cm}^{-1}$ for the samples with $\mathrm{Bi}_{2} \mathrm{O}_{3}$ concentration. This shoulder absorption is assigned to the $\mathrm{BO}_{2} \mathrm{~F}$ units [29] and also may be due to $\mathrm{Bi}-\mathrm{O}-\mathrm{Bi}$ vibrations of $\mathrm{BiO}_{6}$ octahedral units [23]. Furthermore the absorption band centered at $1440 \mathrm{~cm}^{-1}$ and $1530 \mathrm{~cm}^{-1}$ in all the samples except $x=0$, is due to $\mathrm{BO}^{-}$stretching vibrations of $\mathrm{BO}_{3}$ units from varied types of borate groups [30].

All these results are summarized in Table 1.

3.3. Density and Molar Volume. Using Archimedes principle, density $(D)$ of all the samples was calculated, and its values are ploted against $\mathrm{Bi}_{2} \mathrm{O}_{3} \mathrm{~mol} \%$ in Figure 3. It is observed that density of the samples increases with increasing concentration of $\mathrm{Bi}_{2} \mathrm{O}_{3}$. This shows that the atomic and molecular species get more closely packed with the addition of $\mathrm{Bi}_{2} \mathrm{O}_{3}$. The increase of the density of the glasses with the addition of $\mathrm{Bi}_{2} \mathrm{O}_{3}$ is probably attributable to a change in cross-link density and coordination numbers of $\mathrm{Bi}^{3+}$ ions [30]. It is supported by another fact that $\mathrm{Bi}_{2} \mathrm{O}_{3}$ has larger molar mass as compared to $\mathrm{LiF}$, so the replacement of $\mathrm{LiF}$ by $\mathrm{Bi}_{2} \mathrm{O}_{3}$ makes the density to increase.

The molar volume $\left(V_{M}\right)$ of each glass sample was calculated using the formula [31]

$$
V_{M}=\sum \frac{x_{i} M_{i}}{d}
$$

where $x_{i}$ is the molar fraction and $M_{i}$ is the molecular weight of the $i$ th component. It also increases with the increase in $\mathrm{Bi}_{2} \mathrm{O}_{3}$ content.

3.4. Theoretical Optical Basicity. Optical basicity is an important parameter related to the optical properties of the glasses. Electronic polarizability and optical basicity have an intrinsic relationship. Optical basicity is expressed in terms of the electron density carried by anions. Theoretical optical basicity for the present series of samples is calculated using following formula [32]:

$$
\Lambda_{\mathrm{th}}=\sum \frac{\left(Z_{i} r_{i}\right)}{\left(Z_{i}^{\prime} / \gamma_{i}\right)} .
$$

Here $r_{i}$ is the ratio of number of cations " $i$ " to total number of oxide ions, $\gamma_{i}$ is basicity modulating factor, $Z_{i}$ is the oxidation number of cations " $i$ " and $Z_{i}^{\prime}$ is the oxidation number of corresponding anions. The basicity 


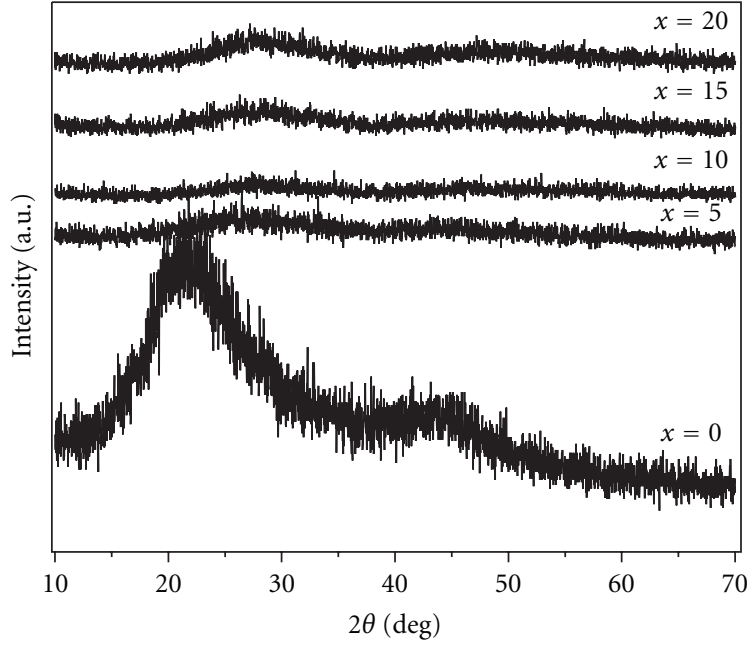

FIGURE 1: XRD plots for samples with $x=0,5,10,15$, and 20 in the compositions $x \mathrm{Bi}_{2} \mathrm{O}_{3} \cdot(40-x) \mathrm{LiF} \cdot 60 \mathrm{~B}_{2} \mathrm{O}_{3}$.

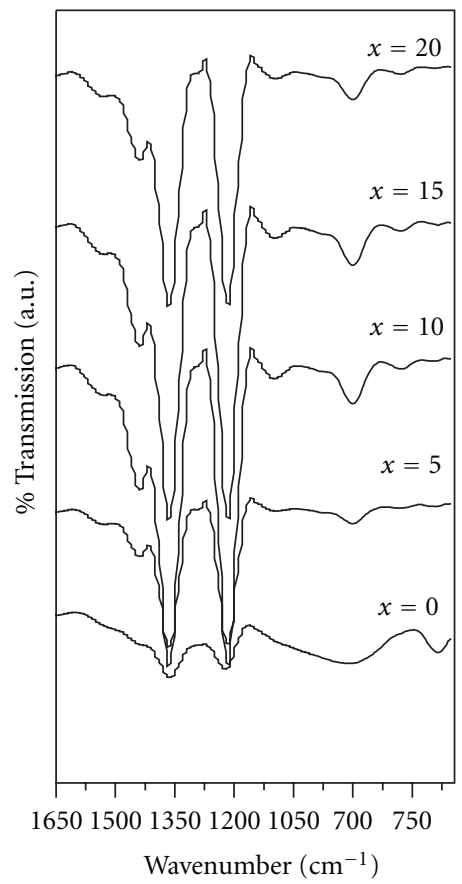

Figure 2: FTIR plots for samples with $x=0,5,10,15$, and 20 in the compositions $x \mathrm{Bi}_{2} \mathrm{O}_{3} \cdot(40-x) \mathrm{LiF} \cdot 60 \mathrm{~B}_{2} \mathrm{O}_{3}$.

moderating parameter " $y_{i}$ " can be calculated from the following equation:

$$
\gamma_{i}=1.36\left(x_{i}-0.26\right),
$$

where " $x_{i}$ " is Pauling's, electronegativity of the cation. Values of $\Lambda_{\text {th }}$ are plotted in Figure 4. It is observed that theoretical optical basicity decreases with increase in $\mathrm{Bi}_{2} \mathrm{O}_{3}$ content.
TABLE 1: FTIR absorption assignments of the samples with $x=0,5$, 10,15 , and 20 in the compositions $x \mathrm{Bi}_{2} \mathrm{O}_{3} \cdot(40-x) \mathrm{LiF} \cdot 60 \mathrm{~B}_{2} \mathrm{O}_{3}$.

\begin{tabular}{|c|c|}
\hline $\begin{array}{l}\text { Wavenumber } \\
\left(\mathrm{cm}^{-1}\right)\end{array}$ & Assignment \\
\hline 685 & Bending of $\mathrm{B}-\mathrm{O}-\mathrm{B}$ linkage in borate network \\
\hline 779 & B-F bonds \\
\hline 901 & $\mathrm{Bi}-\mathrm{O}$ and $\mathrm{Bi}-\mathrm{O}-\mathrm{Bi}$ bands in $\mathrm{BiO}_{6}$ octahedra \\
\hline 910 & $\mathrm{~B}-\mathrm{O}$ bond stretching in $\mathrm{BO}_{4}$ units \\
\hline 1100 & Pentaborate and diborate species \\
\hline 1210,1220 & $\begin{array}{l}\text { Stretching vibrations of } \mathrm{B}-\mathrm{O} \text { bonds in } \mathrm{BO}_{3} \text { units } \\
\text { from meta and orthoborate groups }\end{array}$ \\
\hline 1295 & $\begin{array}{l}\mathrm{BO}_{2} \mathrm{~F} \text { units and } \mathrm{Bi}-\mathrm{O}-\mathrm{Bi} \text { vibrations of } \mathrm{BiO}_{6} \\
\text { octahedral units }\end{array}$ \\
\hline 1365 & $\begin{array}{l}\mathrm{B}-\mathrm{O} \text { asymmetric stretching vibrations in } \mathrm{BO}_{3} \text { and } \\
\mathrm{BO}_{3}{ }^{-} \text {units }\end{array}$ \\
\hline 1370 & $\mathrm{BiO}$ units \\
\hline 1440,1530 & $\begin{array}{l}\mathrm{B}-\mathrm{O}^{-} \text {stretching vibrations of } \mathrm{BO}_{3} \text { units from } \\
\text { varied types of borate groups }\end{array}$ \\
\hline
\end{tabular}

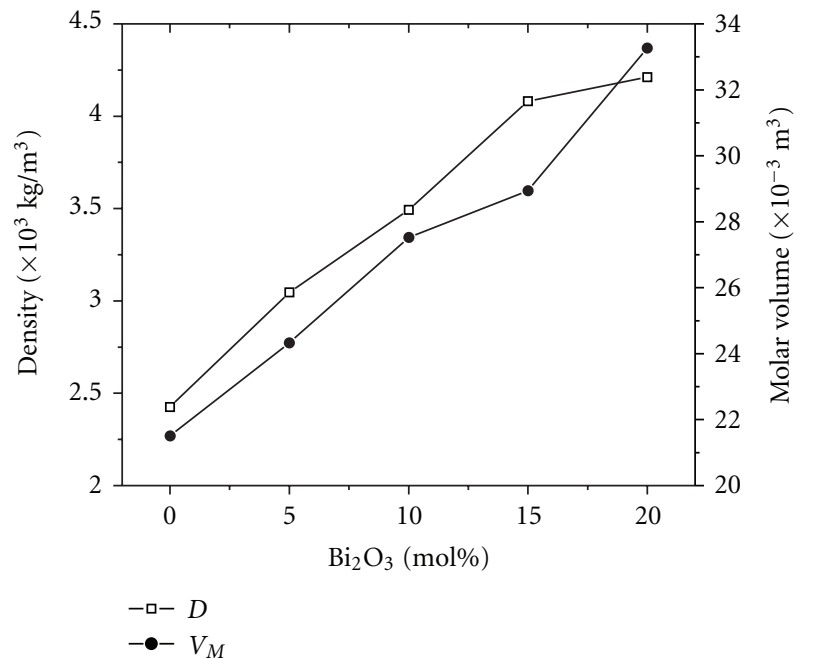

Figure 3: Density and Molar Volume of the samples with $x=$ $0,5,10,15$, and 20 in the compositions $x \mathrm{Bi}_{2} \mathrm{O}_{3} \cdot(40-x) \mathrm{LiF}$. $60 \mathrm{~B}_{2} \mathrm{O}_{3}$.

\section{Conclusions}

Study of the series of amorphous materials with compositions $x \mathrm{Bi}_{2} \mathrm{O}_{3} \cdot(40-x) \mathrm{LiF} \cdot 60 \mathrm{~B}_{2} \mathrm{O}_{3}, x=0,5,10,15$ and 20 reflects following conclusions

(1) XRD analysis, suggests that the samples are amorphous in nature as the XRD spectra of all the samples contain no sharp peak.

(2) In FTIR analysis it can be concluded that $\mathrm{Bi}_{2} \mathrm{O}_{3}$ plays an important role in modifying the glass network. 


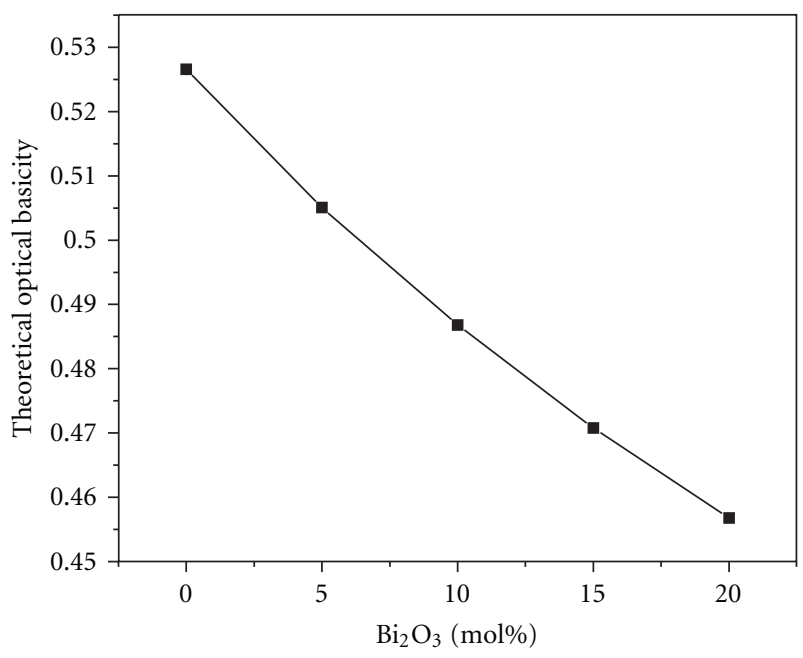

Figure 4: Theoretical Optical Basicity of the samples with $x=$ $0,5,10,15$, and 20 in the compositions $x \mathrm{Bi}_{2} \mathrm{O}_{3} \cdot(40-x) \mathrm{LiF}$. $60 \mathrm{~B}_{2} \mathrm{O}_{3}$.

The presence of the absorption bands at 901, 1295, and $1370 \mathrm{~cm}^{-1}$ attests these modifications which are due to $\mathrm{Bi}_{2} \mathrm{O}_{3}$ content and are absent in the sample with $x=0$. Further, an important conclusion is that with the addition of $\mathrm{Bi}_{2} \mathrm{O}_{3}$ in place of some concentration of LiF, there is an almost elimination of an absorption band $\left(685 \mathrm{~cm}^{-1}\right)$ and shifting of some absorption band centers (1210 to $1220 \mathrm{~cm}^{-1}$ and 1365 to $1370 \mathrm{~cm}^{-1}$ ) from $x=0$ to $x=5$, which approves the role of $\mathrm{Bi}_{2} \mathrm{O}_{3}$ as a network modifier in the present glass system.

(3) Density and molar volume increase with increase in $\mathrm{Bi}_{2} \mathrm{O}_{3}$ content due to replacement of a larger molar mass group $\left(\mathrm{Bi}_{2} \mathrm{O}_{3}\right)$ with a smaller molar mass group (LiF).

(4) Theoretical optical basicity decreases with increase in $\mathrm{Bi}_{2} \mathrm{O}_{3}$ content on the cost of $\mathrm{LiF}$ content.

\section{Acknowledgment}

The financial support provided to one of the authors (S. Arora) by CSIR, New Delhi (India), is gratefully acknowledged.

\section{References}

[1] C. Boussard-Plédel, M. Le Floch, G. Fonteneau et al., "The structure of a boron oxyfluoride glass, an inorganic crosslinked chain polymer," Journal of Non-Crystalline Solids, vol. 209, no. 3, pp. 247-256, 1997.

[2] G. D. Chryssikos, M. S. Bitsis, J. A. Kapoutsis, and E. I. Kamitsos, "Vibrational investigation of lithium metaboratemetaaluminate glasses and crystals," Journal of Non-Crystalline Solids, vol. 217, no. 2-3, pp. 278-290, 1997.
[3] C. Boussard-Plédel, G. Fonteneau, and J. Lucas, "Boron oxyfluoride glasses in the BOF system: new polymeric spaghettitype glasses," Journal of Non-Crystalline Solids, vol. 188, no. 12, pp. 147-152, 1995.

[4] N. Soga, "Elastic moduli and fracture toughness of glass," Journal of Non-Crystalline Solids, vol. 73, no. 1-3, pp. 305-313, 1985.

[5] I. Z. Hager, "Elastic moduli of boron oxyfluoride glasses: experimental determinations and application of Makishima and Mackenzie's theory," Journal of Materials Science, vol. 37, no. 7, pp. 1309-1313, 2002.

[6] I. Z. Hager and M. El-Hofy, "Investigation of spectral absorption and elastic moduli of lithium haloborate glasses," Physica Status Solidi A, vol. 198, no. 1, pp. 7-17, 2003.

[7] J. E. Shelby and L. K. Downie, "Properties and structure of sodium fluoroborate glasses," Physics and Chemistry of Glasses, vol. 30, no. 4, pp. 151-154, 1989.

[8] G. D. Chryssikos, E. I. Kamitsos, A. P. Patsis, M. S. Bitsis, and M. A. Karakassides, "The devitrification of lithium metaborate: polymorphism and glass formation," Journal of NonCrystalline Solids, vol. 126, no. 1-2, pp. 42-51, 1990.

[9] E. I. Kamitsos, A. P. Patsis, and G. D. Chryssikos, "Infrared reflectance investigation of alkali diborate glasses," Journal of Non-Crystalline Solids, vol. 152, no. 2-3, pp. 246-257, 1993.

[10] C. Hwang, S. Fujino, and K. Morinaga, "Density of $\mathrm{Bi}_{2} \mathrm{O}_{3}$ $\mathrm{B}_{2} \mathrm{O}_{3}$ binary melts," Journal of the American Ceramic Society, vol. 87, no. 9, pp. 1677-1682, 2004.

[11] I. I. Oprea, H. Hesse, and K. Betzler, "Optical properties of bismuth borate glasses," Optical Materials, vol. 26, no. 3, pp. 235-237, 2004.

[12] S. Fujiwara, T. Suzuki, N. Sugimoto, H. Kanbara, and K. Hirao, "THz optical switching in glasses containing bismuth oxide," Journal of Non-Crystalline Solids, vol. 259, no. 1-3, pp. 116120, 1999.

[13] N. Sugimoto, "Ultrafast optical switches and wavelength division multiplexing (WDM) amplifiers based on bismuth oxide glasses," Journal of the American Ceramic Society, vol. 85, no. 5, pp. 1083-1088, 2002.

[14] G. Brambilla, F. Koizumi, V. Finazzi, and D. J. Richardson, "Supercontinuum generation in tapered bismuth silicate fibres," Electronics Letters, vol. 41, no. 14, pp. 795-797, 2005.

[15] J. H. Lee, K. Kikuchi, T. Nagashima, T. Hasegawa, S. Ohara, and N. Sugimoto, "All fiber-based 160-Gbit/s add/drop multiplexer incorporating a 1-m-long Bismuth Oxide-based ultrahigh nonlinearity fiber," Optics Express, vol. 13, no. 18, pp. 6864-6869, 2005.

[16] V. Di Noto, M. Bettinelli, M. Furlani, S. Lavina, and M. Vidali, "Conductivity, luminescence and vibrational studies of the poly(ethylene glycol) 400 electrolyte based on europium trichloride," Macromolecular Chemistry and Physics, vol. 197, no. 1, pp. 375-388, 1996.

[17] V. Di Noto, M. Furlani, and S. Lavina, "Synthesis, characterization and ionic conductivity of poly[(oligoethylene oxide) ethoxysilane] and poly[(oligoethylene oxide) ethoxysilane] / $\left(\mathrm{EuCl}_{3}\right)_{0.67}$," Polymers for Advanced Technologies, vol. 7, no. 9, pp. 759-767, 1996.

[18] C. H. Kim, H. L. Park, and S. I. Mho, "Photoluminescence of $\mathrm{Eu}^{3+}$ and $\mathrm{Bi}^{3+}$ in $\mathrm{Na}_{3} \mathrm{YSi}_{3} \mathrm{O}_{9}$," Solid State Communications, vol. 101, no. 2, pp. 109-113, 1997.

[19] A. M. Srivastava, "Luminescence of divalent bismuth in $\mathrm{M}^{2+}$ $\mathrm{BPO}_{5}\left(\mathrm{M}^{2+}=\mathrm{Ba}^{2+}, \mathrm{Sr}^{2+}\right.$ and $\left.\mathrm{Ca}^{2+}\right)$," Journal of Luminescence, vol. 78, no. 4, pp. 239-243, 1998.

[20] L. Baia, R. Stefan, W. Kiefer, and S. Simon, "Structural of characteristics of $\mathrm{B}_{2} \mathrm{O}_{3}-\mathrm{Bi}_{2} \mathrm{O}_{3}$ glasses with high transition 
metal oxide content," Journal of Raman Spectroscopy, vol. 36, no. 3, pp. 262-266, 2005.

[21] B. V. R. Chowdari and Z. Rong, "Study of the fluorinated lithium borate glasses," Solid State Ionics, vol. 78, no. 1-2, pp. 133-142, 1995.

[22] P. Paşcuţa, M. Boşca, S. Rada, M. Culea, I. Bratu, and E. Culea, "FTIR spectroscopic study of $\mathrm{Gd}_{2} \mathrm{O}_{3}-\mathrm{Bi}_{2} \mathrm{O}_{3}-\mathrm{B}_{2} \mathrm{O}_{3}$ glasses," Journal of Optoelectronics and Advanced Materials, vol. 10, no. 9, pp. 2416-2419, 2008.

[23] S. Bale and S. Rahman, "Glass structure and transport properties of $\mathrm{Li}_{2} \mathrm{O}$ containing zinc bismuthate glasses," Optical Materials, vol. 31, no. 2, pp. 333-337, 2008.

[24] A. Bajaj and A. Khanna, "Crystallization of bismuth borate glasses," Journal of Physics Condensed Matter, vol. 21, no. 3, Article ID 035112, 2009.

[25] I. Ardelean and S. Cora, "FT-IR, Raman and UV-VIS spectroscopic studies of copper doped $3 \mathrm{Bi}_{2} \mathrm{O}_{3} \cdot \mathrm{B}_{2} \mathrm{O}_{3}$ glass matix," Journal of Materials Science, vol. 19, no. 6, pp. 584-588, 2008.

[26] V. Kundu, R. L. Dhiman, A. S. Maan, D. R. Goyal, and S. Arora, "Characterization and electrical conductivity of Vanadium doped strontium bismuth borate glasses," Journal of Optoelectronics and Advanced Materials, vol. 12, no. 12, pp. 2373-2379, 2010.

[27] E. I. Kamitsos, M. A. Karakassides, and G. D. Chryssikos, "Vibrational spectra of magnesium-sodium-borate glasses. 2. Raman and mid-infrared investigation of the network structure," Journal of Physical Chemistry, vol. 91, no. 5, pp. 1073-1079, 1987.

[28] F. Chen, S. Dai, Q. Nie, T. Xu, X. Shen, and X. Wang, "Glass formation and optical band gap studies on $\mathrm{Bi}_{2} \mathrm{O}_{3}-\mathrm{B}_{2} \mathrm{O}_{3}$ $\mathrm{BaO}$ ternary system," Journal Wuhan University of Technology, Materials Science Edition, vol. 24, no. 5, pp. 716-720, 2009.

[29] M. El-Hofy and I. Z. Hager, "Ionic conductivity in lithium haloborate glasses," Physica Status Solidi A, vol. 199, no. 3, pp. 448-456, 2003.

[30] A. El-Adawy and Y. Moustafa, "Elastic properties of bismuth borate glasses," Journal of Physics D, vol. 32, no. 21, pp. 27912796, 1999.

[31] E. Mansour, G. M. El-Damrawi, Y. M. Moustafa, S. Abd ElMaksoud, and H. Doweidar, "Polaronic conduction in barium borate glasses containing iron oxide," Physica B, vol. 293, no. 3-4, pp. 268-275, 2001.

[32] J. A. Duffy and M. D. Ingram, "Optical basicity-IV: influence of electronegativity on the Lewis basicity and solvent properties of molten oxyanion salts and glasses," Journal of Inorganic and Nuclear Chemistry, vol. 37, no. 5, pp. 1203-1206, 1975. 


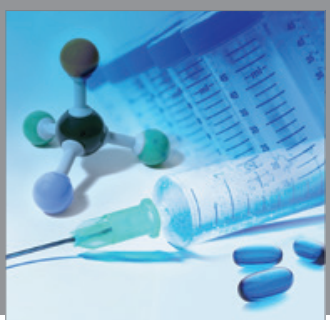

International Journal of

Medicinal Chemistry

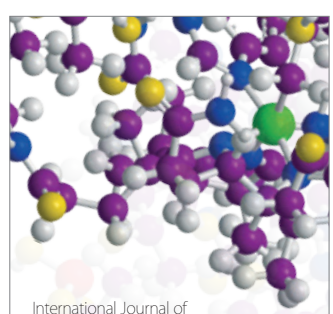

Carbohydrate Chemistry

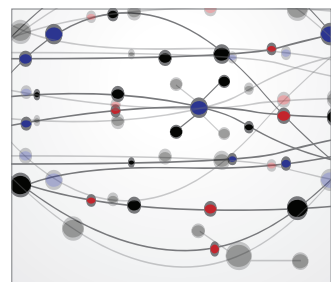

The Scientific World Journal
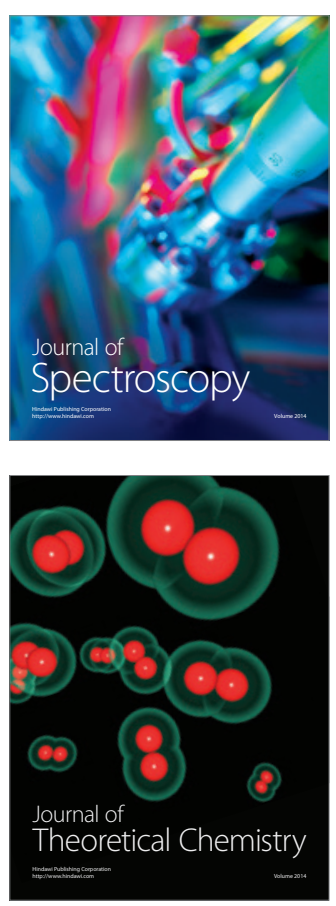
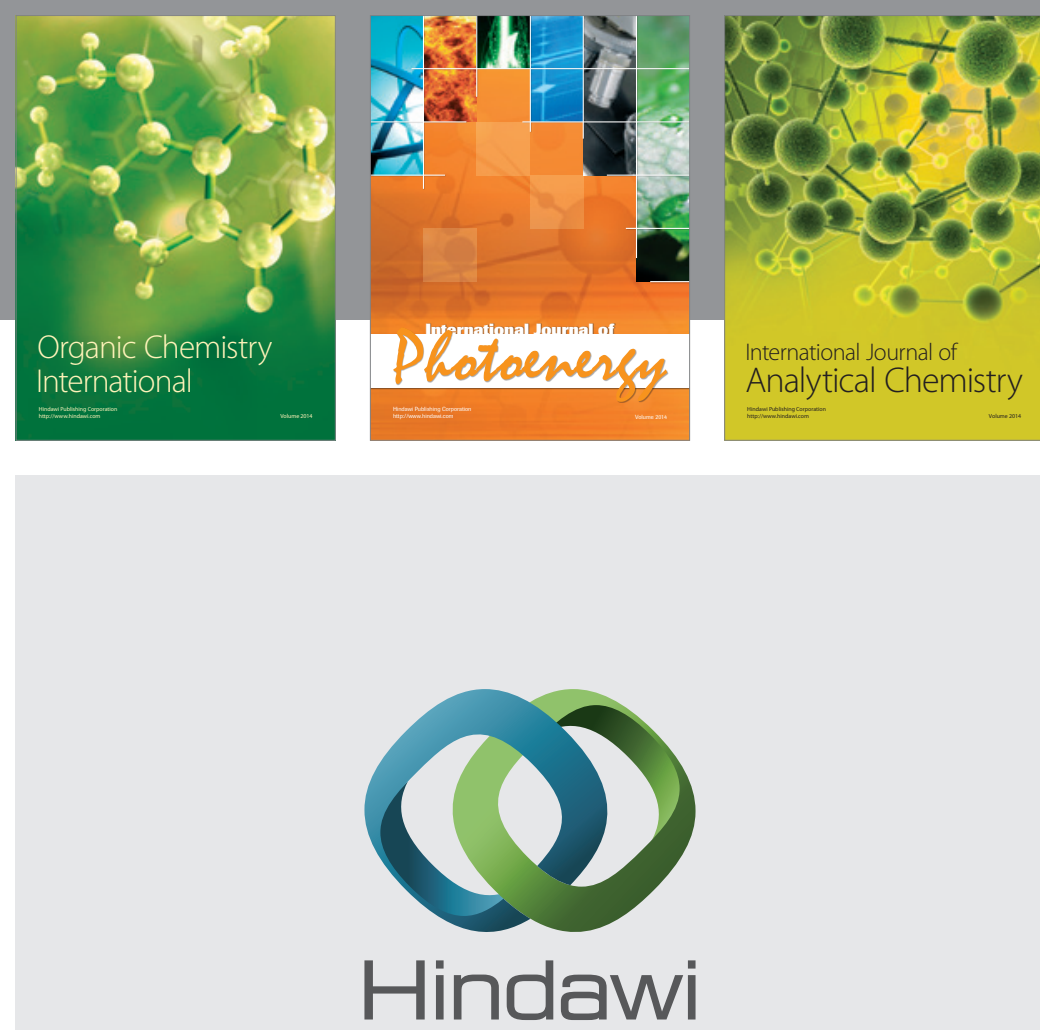

Submit your manuscripts at

http://www.hindawi.com
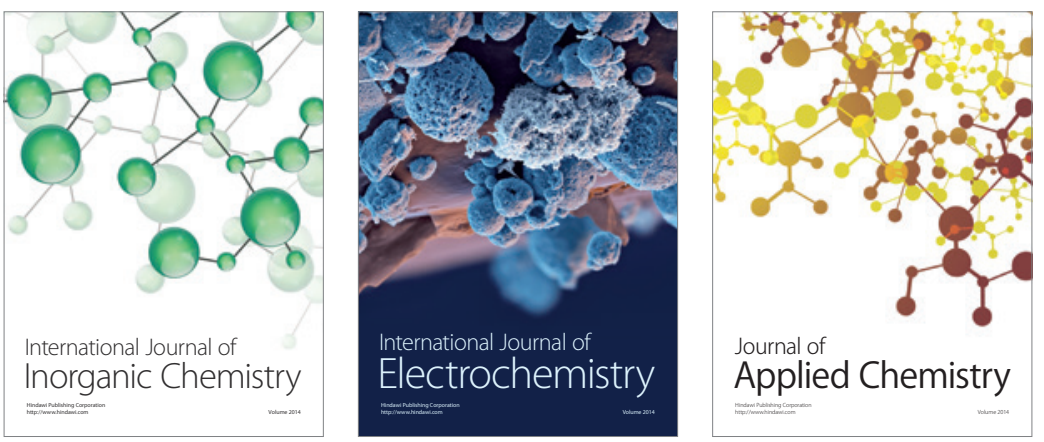

Journal of

Applied Chemistry
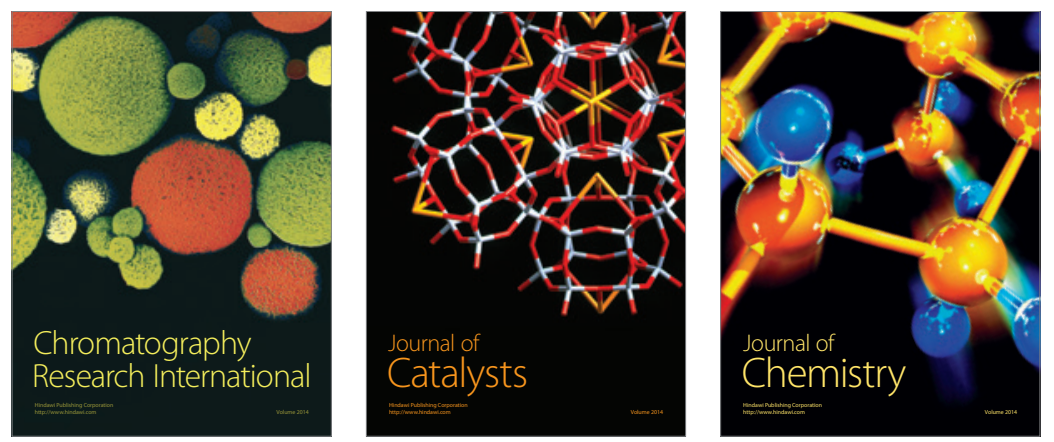
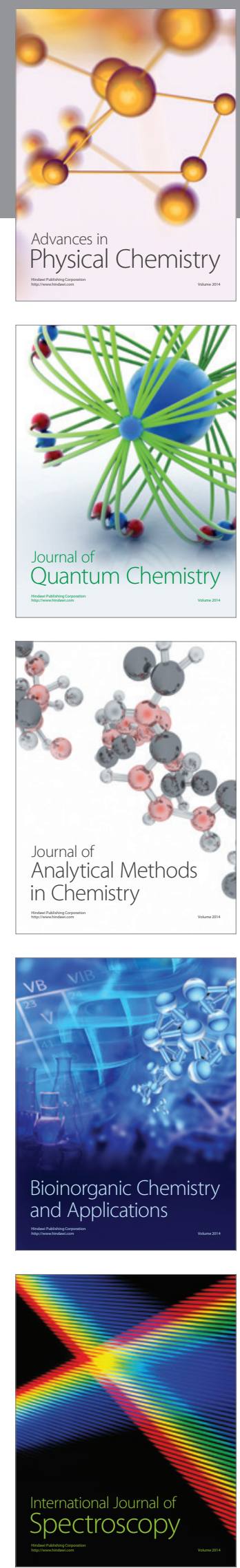